\title{
COMMON BIRCH (Betula pendula Roth.) - CHEMICAL COMPOSITION AND BIOLOGICAL ACTIVITY OF ISOLATES
}

Marijana S. Vladimirov*, Vesna D. Nikolić, Ljiljana P. Stanojević, Ljubiša B. Nikolić, Ana D. Tačić

Faculty of Technology, University of Niš, Leskovac, Serbia

The common birch (Betula pendula Roth., Betulaceae) is widespread in moderate and northern climatic zones. It is used in traditional medicine of many countries, and its positive effects on human health were recognized a long time ago. It belongs to a group of medicinal plants. Numerous studies on the chemical composition and activity of the birch isolates are aimed at confirming their biological effects and the use in traditional medicine. A large number of bioactive compounds have been isolated from buds, juice (sap), leaves and bark of common birch. The composition varies depending on the variety, age of the plant, geographical area, the methods of isolation and the analysis used. However, the chemical composition of the isolates has been partially studied, and further investigations are required. Anti-inflammatory, antimicrobial, antiviral, antioxidant, antiproliferative, antirheumatoid, uteroprotective, antiallergic and gastroprotective activity of the isolates have been established. That opens the possibility of its potential use in the prevention and treatment of a wide spectrum of diseases. Further preclinical and clinical studies are needed in order to create and apply preparations based on common birch isolates.
(REVIEW PAPER)

UDC 582.632.1:577.1:615.1

Keywords: Betula pendula, chemical composition, biological activity

\section{Introduction}

Betula pendula Roth (Betulaceae), or common birch, white birch, European silver birch or European white birch, is a tree or bush-like tree, whose visual feature is white bark. The species is widespread in regions with a moderate climate. It can be found in most parts of Europe, to central Siberia. It grows south to the Iberian peninsula, southern Italy and Greece. It is also found in the northern parts of Asia. Because of its widespread distribution, it shows great morphological variability, and several subspecies and varieties are described. The Plant List contains 22 titles for the Betula pendula criterion - varieties and subspecies of this plant species [1-3].

The common birch contains a large number of bioactive organic compounds such as terpenes, flavonoids, catechins, lignans, some steroidal compounds, and procyanidins. Isolates from different parts of the birch have a different chemical composition. On the other hand, the chemical composition of the isolates from the same parts may vary depending on the applied isolation techniques $[2,4]$.

The available literature describes several types of birch isolates that are used as a medicine in different parts of the world. The widest usage is in the treatment of urinary tract problems, bones, including arthritis, rheumatism, and gout, as well as kidney stones $[2,4,5]$.

Juice from the birch tree and liquid preparations: teas, infusions and decocts prepared from bark, buds and birch leaves are applied in treating arthritis, rheumatism, kidney disease, hypercholesterolemia, colds, heart and liver disease due to their beneficial effects on human health. Birch isolates can also be successfully applied in hair loss prevention, treatment of alopecia, skin diseases (cellulitis), healing of wounds and scars and as diuretics [4].

\section{Birch buds}

Birch buds are collected in the appropriate vegetative period of the plant before opening, preferably in the early spring or before the end of winter. After collection, they are dried in the air to a constant mass, and then the isolates are obtained by different methods. The methods used include distillation methods (hydrodistillation and microdistillation), extraction methods, and simultaneous distillation-extraction methods (Likers-Nickerson method). The isolation and identification of a large number of compounds by distillation and extraction methods have been reported [6].

The chemical composition differs qualitatively and quantitatively depending on the method applied (distillation, extraction, HS-SPME (headspace solid-phase microextraction)), as shown in Tables 1 and 2.

Birch buds have a relatively high content of essential oil which represents the subject of numerous studies. The yield of essential oil differs ranging from $0.5 \%$ up to $3.8 \%$, which depends on the geographical area, a degree of buds formation (seasonal variation) and the isolation method applied $[6,7]$.

\footnotetext{
*Author address: Marijana S. Vladimirov, Faculty of Technology, Bulevar oslobođenja 124, 16000 Leskovac, Serbia

E-mail: marijana89@hotmail.co.uk

The manuscript received: May, 16, 2019.

Paper accepted: June, 10, 2019.
} 
According to the current literature available, two methods of distillation of the common birch essential oil were used in practice, Clevenger hydrodistillation, for 3 or 4 hours, and microdistillation. Distillation can be done with whole or crushed plant material. Microdistillation is a more practical and effective method than hydrodistillation. After the essential oil isolation, a further analysis is performed with analytical techniques. In the determination of terpene compounds, gas chromatography (GC) and a combination of gas chromatography-mass spectrometry (GC-MS) are primarily used. However, there are significant difficulties during the gas chromatogram interpretation, due to the fact that essential oils are usually complex multicomponent mixtures of different compounds. Many of them are characterized by similar physico-chemical properties, including retention chromatographic parameters. Therefore, for the identification of such compounds, specific detection methods are used: mass spectrometry (MS) and infrared spec- troscopy with Fourier transform (FT-IR). As an additional identification parameter, retention indices are used to increase the reliability of identification $[1,6,7]$.

Depending on the used techniques, the apparatus, and the plant material, a greater or lesser number of compounds can be identified. Demirci and Isidorov have been able to identify more than 50 compounds in the common birch buds essential oils in their research $[7,8,13]$. The volatile compounds are from the group of terpenes, such as monoterpene hydrocarbons, sesquiterpene hydrocarbons, monoterpene alcohols, monoterpene carbonyl compounds, monoterpene acetates and esters, sesquiterpene alcohols, esters, and epoxides. Most of the compounds belong to a group of sesquiterpene hydrocarbons and alcohols, followed by monoterpene hydrocarbons and alcohols $[1,6,7]$.

In Table 1, the chemical composition of diethyl ether extract (A) and volatile compounds (B) of whole birch buds is compared.

Table 1. Chemical composition of the diethyl ether extract $(A)$ and volatile compounds (B) of whole white birch buds [8]

\begin{tabular}{|c|c|c|}
\hline Compounds & A & B \\
\hline Monoterpenoids & n.d. & $0.93 \pm 0.19$ \\
\hline Limonene & n.d. & $0.03 \pm 0.02$ \\
\hline (E)- $\beta$-Ocimene & n.d. & $0.43 \pm 0.09$ \\
\hline Linalool & n.d. & $0.07 \pm 0.02$ \\
\hline Sesquiterpene hydrocarbons & n.d. & $86.35 \pm 13.82$ \\
\hline$\alpha-C u b e b e n e$ & n.d. & $1.16 \pm 0.24$ \\
\hline a-Copaene & n.d. & $15.77 \pm 2.84$ \\
\hline$\beta$-Caryophyllene & n.d. & $3.41 \pm 0.68$ \\
\hline a-Humulene & n.d. & $3.97 \pm 0.72$ \\
\hline Aromadendrene & n.d. & $11.33 \pm 1.93$ \\
\hline Alloaromadendrene & n.d. & $6.35 \pm 1.21$ \\
\hline Y-Cadinene & n.d. & $3.22 \pm 0.71$ \\
\hline$\delta$-Cadinene & n.d. & $6.65 \pm 1.33$ \\
\hline Sesquiterpenoids & $0.11 \pm 0.02$ & $5.15 \pm 1.03$ \\
\hline Caryophyllene oxide & n.d. & $1.93 \pm 0.38$ \\
\hline Humulene epoxide II & n.d. & $1.93 \pm 0.39$ \\
\hline Triterpenoids & $90.23 \pm 8.12$ & n.d. \\
\hline Dammaradien-3-one & $0.72 \pm 0.07$ & n.d. \\
\hline Dipterocarpol & $17.21 \pm 1.12$ & n.d. \\
\hline Betulinol & $2.14 \pm 0.17$ & n.d. \\
\hline Flavonoids & $1.40 \pm 0.15$ & n.d. \\
\hline Catechin & $0.03 \pm 0.01$ & n.d. \\
\hline 5,7,4'-Trihydroxy-4-methoxyflavanone & $1.37 \pm 0.11$ & n.d. \\
\hline Aliphatic alcohols & $0.75 \pm 0.10$ & $1.49 \pm 0.34$ \\
\hline Aliphatic acids & $0.76 \pm 0.91$ & n.d. \\
\hline Aliphatic carbonyls & n.d. & $2.06 \pm 0.39$ \\
\hline Aliphatic acids ester & n.d. & $0.10 \pm 0.01$ \\
\hline Alkanes & $1.30 \pm 0.12$ & n.d. \\
\hline Aromatics & n.d. & $3.36 \pm 0.64$ \\
\hline NN & $2.19 \pm 0.28$ & n.d. \\
\hline Total & 96.74 & 99.44 \\
\hline
\end{tabular}

n.d. - non detected; NN - not identified compounds.

The analysis of volatile components from birch buds can also be performed using the HS-SPME method [12]. The chemical composition of volatile compounds extracted was determined by the GC-MS method. A high content of sesquiterpene hydrocarbons $\left(\mathrm{C}_{15} \mathrm{H}_{24}\right)$ and a low content of their oxygen derivatives (Table 1, column $B$ ) was noted. On the 
other side, monoterpenes, aliphatic alcohols, aliphatic hydrocarbons, aliphatic acid esters, and aromatic compounds were found in significantly smaller quantities. The most abundant compounds were a-copaene and aromadendrene. Higher molecular weight compounds (triterpenes and flavonoids) were not detected (Table 1, column B) [8].

The same plant material (whole birch buds) was extracted with diethyl ether, the compounds were converted to TMS (trimethylsilyl) derivatives and then analyzed by GC-MS. The chemical composition differs considerably in comparison to the composition of the same plant sample analyzed by the HS-SPME method. The presence of triter- penes (over 90\%) and, to a lesser extent, sesquiterpenes, and flavonoids (Table 1, column A) has been revealed to a large extent. Volatile compounds such as monoterpenes were not detected using this method [8].

Table 2 shows the chemical composition of the essential oil from the common birch buds obtained by hydrodistillation, and analyzed by GC-MS. Dominant compounds belong to a group of sesquiterpene hydrocarbons, the most abundant being $\alpha$-copaene, germacrene $D$ and $\delta$-cadinene [6].

Table 2. Chemical composition of the essential oil isolated by hydrodistillation from crushed birch buds [6]

\begin{tabular}{|c|c|}
\hline Compound & Content (\%) \\
\hline Hexanal & 0.1 \\
\hline 2-Pentyl furan & $\operatorname{tr}$ \\
\hline p-Cymene & $\operatorname{tr}$ \\
\hline Nonanal & 0.9 \\
\hline a-Cubebene & 0.8 \\
\hline$\alpha-Y l a n g e n e$ & 1.1 \\
\hline a-Copaene & 11.8 \\
\hline$\beta$-Bourbonene & 0.1 \\
\hline$\beta$-Cubebene & 0.7 \\
\hline$\beta$-Ylangene & 1.3 \\
\hline$\beta$-Copaene & 1.0 \\
\hline$\beta$-Caryophyllene & 3.4 \\
\hline 6,9-Guaiadiene & 2.4 \\
\hline Aromadendrene & 0.6 \\
\hline Cadina-3,5-diene & 0.3 \\
\hline Alloaromadendrene & 2.2 \\
\hline epi-Zonarene & 0.6 \\
\hline a-Humulene & 2.9 \\
\hline ү-Muurolene & 2.6 \\
\hline Germacrene D & 11.4 \\
\hline a-Muurolene & 2.0 \\
\hline$\delta$-Cadinene & 10.8 \\
\hline y-Cadinene & 2.4 \\
\hline Cadina-1,4-diene & 0.3 \\
\hline 3,7-Guaiadiene & 0.5 \\
\hline$(E, E)-2,4$-Decadienal & 0.2 \\
\hline Calamenene & 0.3 \\
\hline Geraniol & $\operatorname{tr}$ \\
\hline (E)-Geranyl acetone & 0.1 \\
\hline epi-Cubebol & 0.2 \\
\hline a-Calacorene & 0.7 \\
\hline 1,5-Epoxy-salvial(4)14-ene & $\operatorname{tr}$ \\
\hline Cubebol & 0.3 \\
\hline Dodecanol & 0.1 \\
\hline y-Calacorene & $\operatorname{tr}$ \\
\hline Caryophyllene oxide & 0.5 \\
\hline Salvial-4(14)-en-1-one & 0.4 \\
\hline Humulene epoxide-II & 0.5 \\
\hline Cubenol & 2.7 \\
\hline 1-epi-Cubenol (n.p.) & 5.0 \\
\hline Furopelargone B & 0.9 \\
\hline T-Cadinol & 1.5 \\
\hline T-Muurolol & 0.9 \\
\hline$\delta$-Cadinol & 0.4 \\
\hline a-Cadinol & 2.8 \\
\hline Guaia-6,10(14)-dien-4 $\beta$-ol & 0.1 \\
\hline Tricosane & 0.5 \\
\hline Eudesma-4(15),7-dien-4ß-ol & 0.1 \\
\hline Pentacosane & 1.6 \\
\hline Heptacosane & 0.1 \\
\hline Total & 80.1 \\
\hline
\end{tabular}




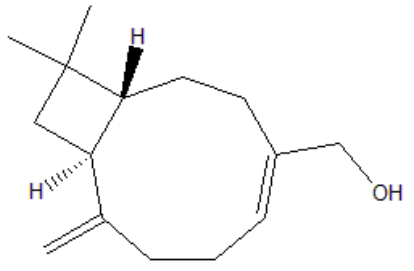

14-hydroxy- $\beta$-caryophyllene

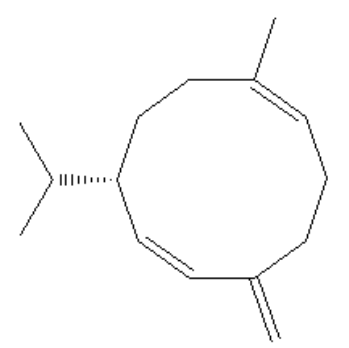

Germacrene D

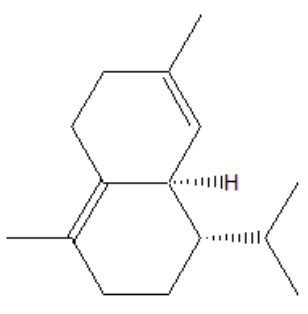

ס-cadinene

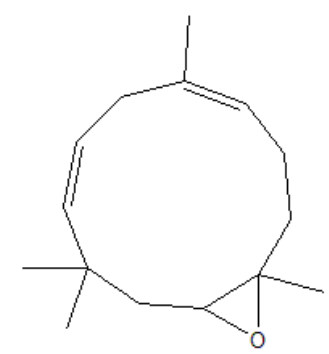

Humulene-epoxide
Figure 1. Structural formulas of sesquiterpenes present in the white birch buds essential oil

Sesquiterpenes are present with more than $60 \%$ of the total oil composition. Their content varies considerably with varieties. The dominant compound in one variety may be present in a negligible amount in another one. Among the sesquiterpenes, the dominant ones are cadinene, selinene, and caryophyllene from the group of bicyclic hydrocarbons (Figure 1) [7-11].

Based on the available literature data, it can be concluded that there is no uniformity in the composition of essential oils isolated from common birch buds. The differences were observed between the samples collected from the same plants over a different period of the year, within the same plant species that grow in different geographical areas, as well as between different common birch varieties. Also, the dominant compounds were different. Common birch buds oil does not have a universally dominant compound, but the chemical composition is variable and depends on many factors $[1,2,4,6-8,10]$.

\section{Birch sap}

The birch sap (juice) has been used in traditional medicine since ancient time, against colds, as a stimulant of appetite, in the treatment of kidney diseases and topically to improve hair growth. It was also used as a source of nutrients in the form of fresh drinks, and also as a food ingredient [12].

The sap is collected in spring, with suitable techniques, from older birch trees. The results of numerous analyses examining its composition indicate that the sap contains natural sugars (glucose, fructose, sucrose), minerals (sodium, potassium, magnesium, calcium, iron and other useful microelements), over 10 organic acids, essential oils, saponins, vitamins A, C and B complex, as well as other biologically active substances (phenolic compounds, flavonoids, tannins and glycosides) [13].

Among the minerals present, birch sap contains the highest amounts of $\mathrm{K}^{+}$and $\mathrm{Ca}^{2+}$, while $\mathrm{Mn}^{2+}$ ions are the most present trace element. The presence of $\mathrm{Mg}$ and $\mathrm{Zn}$ in certain quantities is significant. The dominant anions are sulphate ions, while the concentration of nitrates and nitrites is negligible [14].

Like most plants, common birch shows selective accumulation of soil elements. A good example is a ratio between the concentrations of different alkaline metal ions in the birch sap. The availability of $\mathrm{Na}^{+}$and $\mathrm{K}^{+}$ions in water and rocks is the same, and in the common birch sap, there is $100-1000$ times more $\mathrm{K}^{+}$than $\mathrm{Na}^{+}$[14].

The protein concentration is $127 \mathrm{mg} / \mathrm{dm}^{3}$, and the ascorbic acid concentration is $3.2 \mathrm{mg} / \mathrm{dm}^{3}$. The free amino acid concentration increases during the sap production period. The most present amino acids are glutamine, citrulline and glutamic acid [13].

Carbohydrates were analyzed by using HPLC method (High-Performance Liquid Chromatography), and the presence of glucose, fructose and sucrose was detected. The content of fructose is slightly higher in comparison to glucose and sucrose. The content of other carbohydrates is negligible, and they are not quantified. It has also been shown that the carbohydrate content does not depend on the species and variety of the birch [13].

The total concentration of antioxidants was investigated using quercetin as equivalent, and a moderate antioxidant activity $\left(0.35 \mathrm{mg} / \mathrm{dm}^{3}\right.$ versus quercetin) was obtained [13].

Due to the prevalence of birch in the Northern hemisphere, its sap is relatively accessible for the research. However, a more detailed research of the chemical composition, individual compounds, and their biological activities is needed.

\section{Birch leaf}

The birch leaves have been used since antique times in urinary tract disorders, infections and inflammation, and for the increase of diuresis. According to the European Medicines Agency, the birch leaf is a traditional medication that increases the amount of urine and helps to rinse the urinary tract. It is used as an auxiliary agent in mild infections [15].

According to the $7^{\text {th }}$ European Pharmacopoeia, dried common birch leaves are successfully used as a whole or crushed for medical purposes. Leaves should not contain less than $1.5 \%$ flavonoids, calculated as hyperoside, relative to dry matter [16].

The chemical composition of flavonoids as the main phenolic compounds is quite intensively investigated. Hänsel and Sticher [18] identified the following flavonoids in the birch leaf: quercetin-3-O-galactoside (hyperoside), quercetin-3-O-glucuronide, myricetin-3-O-galactoside, quercetin-3-O-rhamnoside and other glycosides of quercetin (Figure 2) [17]. 

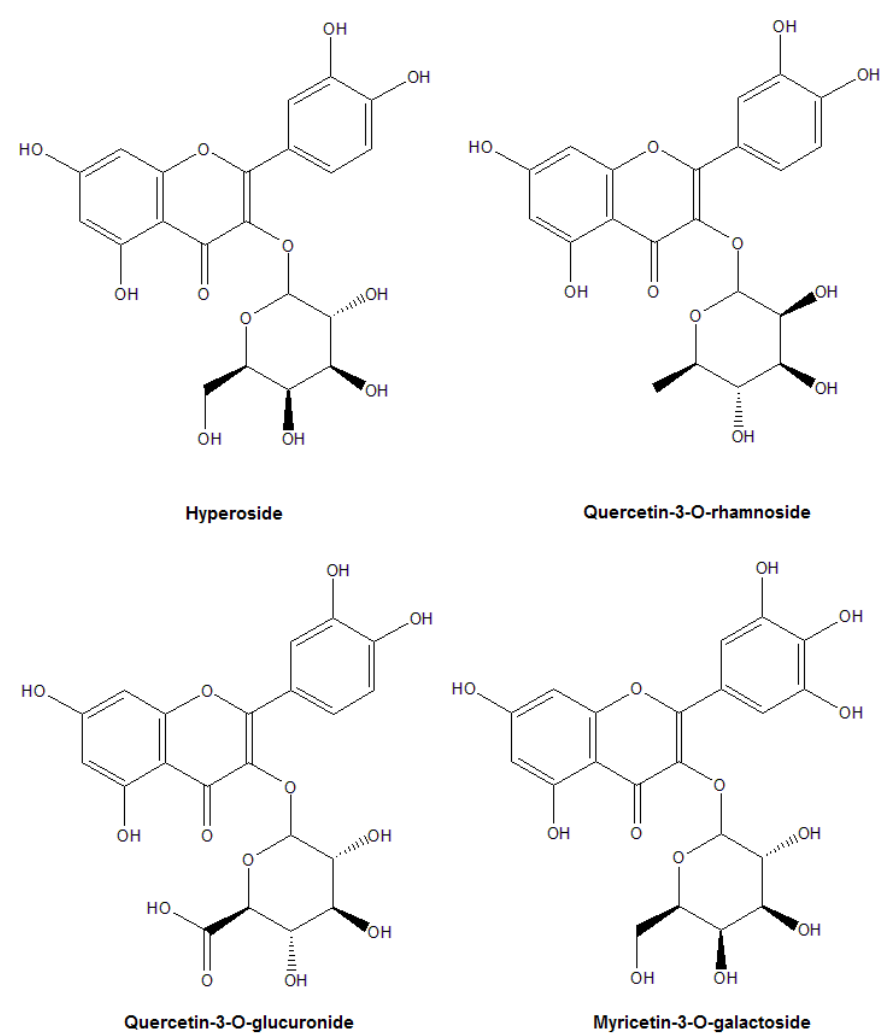

Figure 2. Structures of flavonoids present in the white birch leaves

The birch leaves contain 1-3\% of flavonol glycosides, mainly hyperosids and other quercetin glycosides, as well as glycosides of kaempferol and myricetin. Among others, it contains phenolic compounds (3,4'-dihydroxypropionophenone-3-glucoside, caffeine and chlorogenic acid), lignans, diarylheptanoids, triterpenes, and damaronic type malonyl esters and saponosids [17].

The seasonal dynamics of hydrosoluble phenols of common birch leaves in different urban environments and different vegetation periods were studied [17]. The highest content of phenols is recorded in the first and second decade of May, the content of phenols decreases in mid-July, and grows in late summer and autumn. There is a tendency of a decrease of the phenol content during dry years. The flavonoid content was higher in young leaves than in the old ones [17].

In the extract of the birch leaves extracted with carbon dioxide, 33 compounds were identified. The most abundant were the following compounds: $\alpha$-pinene $(2.22 \%)$, bornyl acetate $(2.736 \%)$, lambertic acid $(2.488 \%)$ and $n$-tricosane $(2.50 \%)$. Common birch also contains an essential oil (0.04-0.63\%), vitamins (2-8\%), ascorbic acid, nicotinic acid, carotenes, coumarins $(0.44 \%)$, tannins (5$9 \%$ ), saponins (up to $3.2 \%$ ) and sterols [17].

The essential oil of birch leaves could be obtained by hydrodistillation of dried and crushed leaves, yielding from 0.04 to $0.63 \%$. Its yield depends on the plant geographical origin. The analysis of the essential oil composition is carried out using the GC and GC-MS methods, and the identification of compounds present is based on mass spectra and retention indices comparison with reference standards and literature data [16-18].

The chemical composition of the investigated essential oils differs in the presence and the content of chemical compounds, but the dominant group of compounds is sesquiterpenes (caryophyllenes, humulenes etc.). The leaf is a rich source of caryophyllene derivatives which are of great interest in the field of chemistry of natural products [17-19].

\section{Birch bark}

Due to its characteristics and effectiveness, birch bark was appreciated even during the prehistoric and historic period, and it is still a subject of interest in the science and pharmaceutical industry. The current extensive research is carried out in the field of pharmaceutical and cosmetic industry. Triterpenes present in the bark, representing a new class of promising anti-cancer and anti-HIV bioactive compounds with a new mechanism of action attract most attention. Birch bark extracts have been widely used in modern cosmetics, and have a potential usage as dietary supplements [19].

The extracts represent a mixture of pentacyclic triterpenes. A lupane type is more abundant than the oleane type of triterpenes. These bioactive compounds are used as dietary supplements, biocides and bactericides in pharmaceutical and cosmetic industries. The average content of certain compounds in common birch extracts is shown in Table 3. Chemical structures of the most presented compounds are shown in Figure 3. Differences in the chemical composition occur depending on the age of the sample, climatic and vegetational conditions, as well as on the extraction technique used. Different methods of the analysis and lack of a standard calibration procedure can also be the reason for variations [19].

Table 3. Average chemical composition (\%) of triterpenes present in white birch bark extracts [19]

$\begin{array}{cc}\text { Compound } & \text { Content (\%) } \\ \text { Betulin } & 78.1 \\ \text { Betulinic acid } & 4.3 \\ \text { Betulin aldehyde } & 1.2 \\ \text { Lupeol } & 7.9 \\ \text { Oleanolic acid } & 2.0 \\ \text { Betulin-3-caffeate } & 0.5 \\ \text { Erythrodiol } & 2.8 \\ \text { Others } & 3.2\end{array}$

The following less abundant components (the rest in Table 3) should be mentioned: betulone, betulonic aldehyde, lupenone, betulonic acid, oleanolic aldehyde and $\beta$-amyrin [19].

In comparison to other species, the outer birch bark from northern forests contains the largest amount of triterpenes, up to $20-35 \%$. It is assumed that the physiological function of these compounds is the defense against plant pathogens, which suggests that triterpenes can also be useful against pathogens that cause human and animal diseases. However, the use of natural products, 
including birch bark triterpenes is rather limited. The main reason for this is poor solubility $(<1 \mathrm{mg} / \mathrm{L}$, in water), high log $P$ value $(>9)$ and high molecular weight $(>500$ Da) [29]. Natural birch-based products are important precursors in the synthesis of a large number of synthetic derivatives of lupanes and oleanes [19].
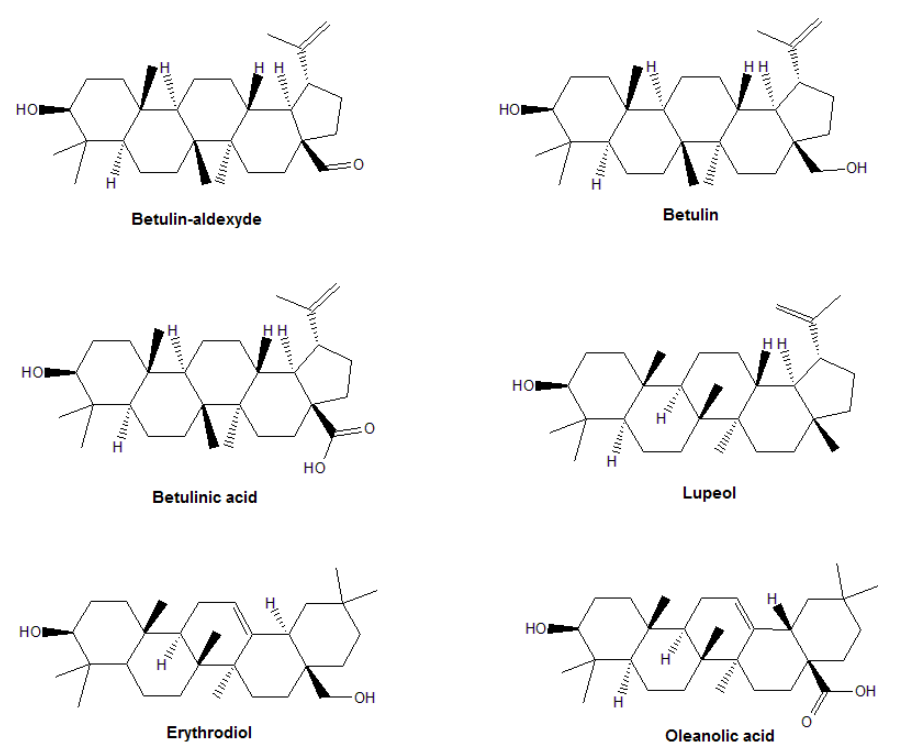

Figure 3. Structures of the most common triterpenes present in the white birch bark

Triterpenes can be extracted from the outer bark of the birch with a large number of different organic solvents, in $20-40 \%$ yields. The yield obtained depends on the type of the solvent and the extraction techniques [19].

A pre-treatment of herbal samples with boiling water and sodium carbonate can increase the content of triterpenes in ethanolic birch extracts from $66.7 \%$ to $99 \%$. The increase of the triterpenes content is the result of decreasing solubility of phenols and monosaccharides in boiling water. The addition of sodium carbonate eliminates monosaccharides and phenols and significantly increases the content of betulin in subsequent extractions with organic solvents. It can be concluded that the content of phenolic compounds and monosaccharides can be greatly reduced with boiling water and a sodium carbonate pre-treatment. In that way, the yield of betulin and other triterpenes by polar solvents extraction can be significantly increased [20].

The composition of the obtained extracts varies depending on the solvent used. In the research of Rizhikov et al. [20], the extraction was done with the following solvents: ethanol, methanol, acetone, chloroform, dichloromethane, benzene, cyclohexane, n-heptane, petroleum ether and n-hexane. The analysis of the extracts obtained was performed using GC-MS method. The results showed that the extracts obtained using polar solvents contain 6 times greater content of phenolic compounds that were responsible for the brown color of the extracts. In the case of nonpolar solvents, the color of the extracts is white, indicating the high content of betulin and other triterpenes. The yield of lupeol did not vary significantly in the extracts obtained by using polar and nonpolar solvents (1.2-2.5\%), indicating its good solubility in solvents of different polarities. The content of betulin and the total extraction yield is quite smaller in the extracts obtained with nonpolar solvents relative to those obtained by polar solvents (Table 4). Nonpolar solvents have advantages over polar solvents because after recrystallization there is no formation of undesirable solvates or hydrogen bond formation between betulin and one or two solvent molecules. The content of phenolic compounds is also much lower. However, polar solvents are less toxic or even non-toxic, and therefore the use of the extracts obtained using polar solvents in the cosmetic, dietary supplements industry or pharmaceutical industry is possible. It is also possible to improve the content of triterpenes in the extract by modifying the extraction process and using the appropriate solvents [20].

Table 4. Extraction yield and the triterpene content in the extracts of the white birch external bark [20]

\begin{tabular}{cccccc}
\hline Solvent & $\begin{array}{c}\text { Extraction } \\
\text { yield }\end{array}$ & Betulin & Lupeol & Admixtures & $\begin{array}{c}\text { Relative } \\
\text { polarity of } \\
\text { solvents } \\
\text { used }\end{array}$ \\
Cyclohexane & $8.3 \pm 0.5$ & 6.1 & 1.5 & 0.7 & 0.006 \\
n-Hexane & $4.5 \pm 0.4$ & 1.5 & 1.8 & 1.2 & 0.009 \\
Petroleum ether $100-140^{\circ} \mathrm{C}$ & $7.8 \pm 0.6$ & 4.8 & 2.2 & 0.8 & 0.011 \\
Benzene & $17.6 \pm 0.8$ & 11.1 & 2.0 & 4.5 & 0.111 \\
n-Heptane & $4.1 \pm 0.9$ & 1.9 & 1.2 & 1.0 & 0.012 \\
Chloroform & $33.3 \pm 1.4$ & 24.3 & 2.5 & 6.5 & 0.259 \\
Dichloromethane & $33.0 \pm 1.0$ & 21.3 & 2.2 & 9.5 & 0.309 \\
Acetone & $33.9 \pm 1.2$ & 25.0 & 2.0 & 6.9 & 0.355 \\
Ethanol & $36.2 \pm 0.5$ & 22.3 & 2.2 & 11.7 & 0.654 \\
Methanol & $34.5 \pm 0.9$ & 24.3 & 2.4 & 7.8 & 0.762 \\
\hline
\end{tabular}

It was discovered that a certain amount of essential oil could be found in the common birch bark, too [9]. Its yield (about $0.1 \%$ ) is lower compared to the yield of the essential oil present in leaves and buds. The essential oil was obtained by hydrodistillation, and its chemical composition was determined using GC and GC-MS methods. It was found that 14-hydroxy- $\beta$-caryophyllene $(19.8 \%)$ was the dominant component. A high content of 14-hydroxy-4,5-dihydro- $\beta$-caryophylene, $\alpha$-humulene, des-4-methylcarphyl-8(14)-en-5-one, $\beta$-betulenal and humulene epoxide II was also observed. Based on the results obtained, it can be concluded that the composition of the bark essential oil is similar to that of buds [9].

Birch bark is a valuable source of triterpenes with a wide range of biological and pharmaceutical activities. Therefore, a further research in this field is important in terms of selecting suitable techniques for the extraction and isolation of certain bioactive compounds, testing their biological activity and future application $[19,20]$.

Biological activity of the isolate from the common birch

The presence and use of birch in medicine have been known since ancient times, and its application in various types of diseases and organism disorders has initiated a large number of pharmacological investigations. Based on the results of the studies performed, common birch isolates exhibit anticancer, antioxidant, antimicrobial, antiviral, antirheumatoid, uroprotective and antiallergic activity. 


\section{Anticancer activity}

In recent decades, there has been an ongoing search for new natural active substances with potential anti-cancer effects. According to previous studies, the common birch bark is a rich source of biologically active substances with an anticancer activity. Active components are certainly pentacyclic triterpenes, and it is assumed that their effect is synergistic with the effects of other compounds present in the bark. Between bioactive compounds present, betulin and betulinic acid should especially be distinguished. The advantage of birch bark isolates over conventional drugs is their greater selectivity and lower systemic toxicity. The extracts showed a strong antitumor, cytotoxic and antiproliferative activity [4,21-24].

Goun et al. [21] investigated the antithrombin activity and the activity against leukemia of 45 different plants. Among these, the common birch extract in methylene chloride and methanol showed the inhibitory effect on the growth of mouse leukemia cells. Positive (methotrexate) and negative control were used. The percentage of inhibition was calculated in relation to a negative control. The extracts showed the activity of $99 \%$ (methylene chloride extract) and $91 \%$ (methanol extract), which is considered to be a strong anticancer activity. Although it showed a weaker activity, a methanol extract has an advantage over a methylene chloride extract because it does not cause cell necrosis.

In the study developed by Calliste et al. [22], the antiproliferative and antioxidant activity of 7 plant species was determined in order to discover new natural active substances. The extraction was carried out by sequential percolation using five solvents of different polarities. The antioxidant activity was determined by DPPH (2,2-diphenyl-1-picrylhydrazyl) assay, and the antiproliferative activity was tested in vitro on B16 melanoma cells. Nonpolar fractions of the plants studied showed the lowest antioxidant activity, but the strongest cytotoxic activity against B16 melanoma cells. The extracts of powdered common birch bark exhibited a strong antiproliferative (nonpolar fractions, dissolved in chloroform and hexane) and antioxidant activity (polar, methanol and water fractions) [22].

Soica et al. [23] investigated in vitro the antiproliferative activity of a common birch bark extract, betulin and betulinic acid standards on three human cell lines: HeLa - cervix adenocarcinoma, MCF7 - breast adenocarcinoma and A431 - carcinoma of the skin epidermis using MTT ([3-(4,5-dimethylthiazol-2-yl)-2,5-diphenyltetrazole bromide] test. Soxhlet extraction was done using a mixture of chloroform, dichloromethane and methanol in the ratio $1: 1: 1 \mathrm{v} / \mathrm{v} / \mathrm{v}$ as a solvent. It has been found that the common birch bark extract has a strong antiproliferative activity, which can be compared with the activity of pure betulin and betulinic acid.

The antiproliferative activity of birch bark extract has also been investigated on tumor cell lines by Dehelean et al. [4]. The results showed that it does not differ sig- nificantly from the activity of the main component, betulin. For that reason, betulin and a common birch bark extract can be considered as important therapeutic agents in the pathology of the skin and other organs, where antiproliferative changes, including solid tumors, are observed. The results also revealed significant efficacy of both extracts and betulin against A431 and HeLa lines. The concentration range in which the inhibition of cancer cell proliferation has been achieved $(70-80 \%)$ is of practical significance, especially in cases of local administration. In vitro data suggest a high activity of betulin as an anticancer agent [4].

The effect of a common birch bark extract containing over $90 \%$ betulin on inhibition of the cell growth was tested in vitro on 4 malign tumors cell lines (epidermal carcinoma, ovarian cancer, adenocarcinoma of the cervix and breast adenocarcinoma) [4]. All the prepared extracts showed a significant antiproliferative activity against tumor cells. Significant differences in the content of betulin and betulinic acid in the extracts did not show any difference in an antiproliferative activity. The reason for these results may lie in the presence of other active natural substances in the birch bark, including flavonoids [4].

Although botulin still does not have extensive use, it is considered that it can be used in the future as an important natural compound and as a precursor for the production of other biologically active compounds. Betulin can be converted into betulinic acid that has a wide range of biological and pharmacological activities. The antitumor activity of betulin, betulinic acid and its derivatives can be of therapeutic significance, as they show the activity against various types of cancer (leukemia, melanoma, cervix adenocarcinoma, breast cancer, epidermal adenocarcinoma of the skin), with a negligible activity on host cells. This activity indicates the selective action of betulinic acid. Betulinic acid derivatives have shown a cytotoxic activity in micromolar or even nanomolar concentrations that can be compared with some clinically used drugs. However, further preclinical animal studies are needed to confirm the efficacy of betulinic acid and its derivatives in vivo [4,21-24].

\section{Antioxidant activity}

Reactive oxygen species such as superoxide anion, hydroxyl radical and hydrogen peroxide are highly reactive molecules responsible for many cell disorders due to their effect on proteins, DNA and lipid peroxidation. By modifying the oxidative balance, they represent important mediators of the cell damage and play an important role in the initiation of many diseases [22].

Herbal antioxidants have a complex mechanism of action, and at the same time a smaller effect on the body, while many synthetic antioxidant compounds have shown toxic and/or mutagenic effects. This is the main reason why natural antioxidants have become important. Many literature data show a simple relationship between the content of phenolic compounds and the antioxidant 
capacity of plant extracts, indicating that they act as reducing agents and donors of hydrogen in two tests (DPPH, ABTS ([2,2'-azinobis-(3-ethylbenzothiazoline6-sulfonate)]). Because of this, phenolic compounds are major antioxidants in plants [5].

For now, common birch is considered as a promising and rich source of natural antioxidants. Further research aims to determine the antioxidant capacity and a preventive activity against the oxidative stress caused by UV radiation and other harmful agents, as well as the potential use of the extracts obtained from various parts of common birch isolates in the prevention and treatment of certain diseases [4,5,22,25-27].

In the research of Calliste and al. [22], the antioxidant activity of certain plant species, including common birch, was investigated. Powdered bark was percolated with a few solvents of different polarities, such as hexane, chloroform, ethyl acetate, methanol and water. The activity in capturing free radicals was determined by electron spin resonance (ESR) spectroscopy. It has been found that most of the polar extract fractions possess the high antioxidant activity. The aqueous and methanolic extract showed a particularly good antioxidant activity based on the presence of phenolic components. The results of this paper represent a good basis for further use of birch extracts as protectors from oxidative stress, such as UV radiation.

In the study of Mashentseva et al. [5], the antioxidant activity of ethanolic extracts of various common birch vegetative organs was compared and investigated. Experiments were carried out in vitro and in vivo on rats using various methods such as the assessment of the extracts ability to remove DPPH radicals, ABTS cationic radicals and hydrogen peroxide or to bond metals as a chelate agent. Phospholipid oxidation processes were studied using acute hypoxia in rats. The change in the relationship between acidic and neutral phospholipids was used to evaluate the birch extract effect on brain tissue. It has been found that rats experiencing ischemia had a reduced amount of acidic phospholipids in homogenates. A preventive injection of the birch extract led to the normalization of the phospholipid ratio. The extract of young branches showed the strongest activity for the neutralization of DPPH radicals, due to the highest content of total flavonoids. The bark extract on the other side exhibited the strongest activity in capturing ABTS cations. The antioxidant activity of buds extract on the lipid peroxidation process in the rat brain tissue was identical to the activity of the standard, vitamin $\mathrm{E}$. These facts point to the possibility of using the common birch extract in regulation of the phospholipid ratio in experimental rats, as well as in the evaluation of exogenous substances antioxidant effect [5].

\section{Antimicrobial and antiviral activity}

Antimicrobial activity of natural substances is crucial for their use in many areas, including medicine, alternative medicine, food industry, etc. It is of great importance because of the increased resistance of some bacterial species to the most commonly used antimicrobial agents [28].

Methanolic extracts derived from common birch bark, flowers, leaves and buds have been tested for antimicrobial activity against Gram-positive and Gram-negative microorganisms. Triterpene compounds, such as betulin, betulinic acid, oleanolic acid and lupeol isolated from outer parts of the bark were also tested for antibacterial activity against Gram-positive bacteria Bacillus subtilis and Staphylococcus aureus, and Gram-negative bacteria Escherichia coli and Pseudomonas aeruginosa. The most pronounced antibacterial activity showed oleanolic acid on $B$. subtilis and $S$. aureus, while E. coli showed resistance to all tested samples. Isolates of bark, buds, flowers and leaves have shown antimicrobial, antifungal and antiviral activity on different types of pathogens [28].

In the research of Demirci et al. [29], the antimicrobial activity of certain compounds derived from birch buds essential oils of five Betula species was studied using the microdilution test. Chloramphenicol was used as a reference standard for all microorganisms tested, except Candida glabrata. The results of the study showed a moderate activity of essential oil compounds on Grampositive and Gram-negative bacteria. Ketoconazole was used as a standard against C. glabrata, and moderate essential oil activity was also observed. It has been shown that 14-hydroxy- $\beta$-caryophyllene exhibits the antibacterial activity on $B$. subtilis and $E$. coli. The results of microbiological tests are shown in Table 5.

Table 5. Minimal inhibitory concentrations $\left(\mathrm{MIC}, \mathrm{mg} / \mathrm{dm}^{3}\right)$ obtained by the microtiter dilution method [29]

\begin{tabular}{lcccccc}
\hline Microorganism & $\begin{array}{c}\text { 14-Hydroxy- } \beta \\
\text { caryophyllene }\end{array}$ & $\begin{array}{c}\beta- \\
\text { caryophyllene }\end{array}$ & $\begin{array}{c}\text { 14-Hydroxy- } \\
\text { isocaryophyllene }\end{array}$ & $\begin{array}{c}\beta- \\
\text { betulenal }\end{array}$ & $\begin{array}{c}\text { 14-acetoxy- } \beta \text { - } \\
\text { caryophyllene }\end{array}$ & $\begin{array}{c}\mathbf{S t} \\
\mathbf{\mu g / c}\end{array}$ \\
$\begin{array}{c}\text { Escherichia coli } \\
\text { Staphylococcus }\end{array}$ & 250 & 250 & 250 & 250 & 250 & 250 \\
$\quad$ aureus & 250 & 250 & 250 & 250 & 250 & 7.81 \\
$\begin{array}{c}\text { Micrococcus } \\
\text { Iuteus }\end{array}$ & 250 & 250 & 250 & 250 & 250 & 125 \\
$\begin{array}{c}\text { Pseudomonas } \\
\text { aeruginosa }\end{array}$ & 250 & 250 & 250 & 250 & 250 & 62.5 \\
$\begin{array}{c}\text { Bacillus cereus } \\
\text { Candida glabrata }\end{array}$ & 125 & 125 & 125 & 250 & 125 & 125 \\
\hline
\end{tabular}

$\mathrm{St}$ - Chloramphenicol, $\mathrm{St}^{*}$ Ketoconasole

The essential oil of birch leaves tested on several types of fungi (Cephalosporium aphidicola, Trichoderma harzianum, Drechslera sorokinianse, Aspergillus quadrilineatus, Aspergillus flavus, Fusarium solani, Rhizoctonia cerealis, Gibberella fujikuroi, Trichothecium roseum) at the concentration of $400 \mu \mathrm{g} / \mathrm{cm}^{3}$ showed a significant antimycotic activity. It has been observed that essential oil completely inhibits the growth of $C$. aphidicola and $R$. cerealis. It had a strong activity against $D$. sorokinase (87.5\% inhibition) and it was moderately active (50\% inhibition) against $T$. roseum, T. harzianum and $F$. solani. The inhibitory effects on the growth of fungi varied, depending on the examined strain [18].

The antimicrobial activity of various parts of common birch should be further investigated, especially when they are used as herbal remedies. Also, the use of birch in the prevention and treatment of various human infec- 
tions can be very useful and desirable $[18,28,29]$.

In vitro antiviral activity of the common birch extract and its main pentacyclic triterpenes (betulin, lupeol and betulinic acid) against Herpes simplex virus type 1 (HSV1) was also investigated [31]. Both the extract and the triterpenes tested exhibited high levels of antiviral activity against HSV-1. The infectivity of acyclovir-sensitive and acyclovir-resistant HSV-1 clinical isolates was significantly reduced by all tested components. To determine the mechanism of antiviral activity, the bark extract and the examined compounds have been added at different stages of the viral infection. The addition of these compounds to non-infected cells before infection or to cells infected with the herpes virus during intracellular replication had little effect on the virus propagation and poor virucidal activity. However, the birch extract and tested compounds showed a high activity when viruses were treated before the infection. Pentacyclic triterpenes inhibited acyclovir-sensitive and acyclovir-resistant clinical isolates of HSV-1 at an early stage of infection. Clinical trials are required for the assessment of in vivo antiherpetic activity of the birch bark extract [30].

In recent years, there have been ongoing studies of the plant triterpene activity against HIV (Human immunodeficiency virus) virus. Considering that existing therapeutic drugs are insufficiently effective, great attention is paid to new, potential natural and semi-synthetic drugs. Semi-synthetic derivatives have shown a stronger activity than naturally isolated betulin, betulinic acid and oleanolic acid. These compounds can serve as a basis for the synthesis of new anti-HIV drugs. Several betulinic acid derivatives are potent and highly selective inhibitors of HIV-1 viruses. In some studies [20,32], betulinic acid and its derivatives have shown moderate inhibitory effect on HIV-1 reverse transcriptase, as well as HIV-1 protease. Betulinic acid derivatives are potential new HIV-1 therapeutics and further studies of mechanisms of their action will probably more precisely define the use of these compounds and clarify the basic biology of HIV-1 fusion and maturation. The primary advantage of triterpenes as biologically active substances is their low toxicity $[19,31]$.

\section{Antireumatoid activity}

Rheumatoid arthritis is a chronic systemic inflammatory disease that affects about $1 \%$ of the population around the world. The preponderant symptoms are pain, stiffness and swelling of joints. One of frequent use of birch in traditional medicine in several countries across Europe is against arthritis and rheumatism. Several studies were conducted to confirm these claims $[4,32]$.

Havlik et al. [33] studied the in vitro inhibitory effect of plants traditionally used against gout, arthritis and rheumatism in the Czech Republic and regions of Central and Eastern Europe on xanthine oxidase. Since gout and nephrolithiasis are the result of registered hyperuricemia, the accumulation of urine monosodium crystals in joints and kidneys also occurs. The xanthine oxidase is the target enzyme for drugs used in reducing urate in hyperuricemia. Betula pendula and Populus nigra have shown the strongest potential for the inhibition of xanthine oxidase in the study. The $80 \%$ ethanolic and methylene chloride-methanolic extracts from buds and leaves of these plants were examined. Common birch is the most active because it contains salicylates and other phenols. This study confirms the use of birch as an efficient antirheumatic and anti-gout agent in traditional medicine.

Gründemann et al. [32] investigated the effect of the common birch extract on human lymphocytes compared to the synthetic drug, methotrexate. It is known that peripheral blood lymphocytes play an important role in the process of initiating an autoimmune response in rheumatoid arthritis, and the higher number of these cells can be caused by dysregulation of proliferation and apoptosis. The lymphocytes proliferation and mitosis were measured based on the activity of mitochondrial dehydrogenases using a colored permeable membrane. Apoptosis was analyzed by comparing the birch and methotrexate extract using flow cytometry and photometric analysis. Depending on concentration values, a birch extract inhibited the growth and mitosis of activated lymphocytes in the corresponding percentages (CD8+: $40 \mathrm{mg} / \mathrm{cm}^{3}-45 \%$; $80 \mathrm{mg} / \mathrm{cm}^{3}-60 \%$; $\left.160 \mathrm{mg} / \mathrm{cm}^{3}-87 \%\right)\left(\mathrm{CD} 4+: 40 \mathrm{mg} / \mathrm{cm}^{3}-\right.$ $33 \%, 80 \mathrm{mg} / \mathrm{cm}^{3}-54 \%, 160 \mathrm{mg} / \mathrm{cm}^{3}-79 \%$ ). The extract does not affect T-lymphocytes that are in the state of rest. The inhibition of lymphocyte proliferation due to induction of apoptosis and stopping the cell cycle was comparable to methotrexate. This study provides a rational basis for the use of the birch leaf extract in the treatment of immune disorders such as rheumatoid arthritis, due to its reducing effect on proliferation of inflammatory lymphocytes.

It is assumed that the antirheumatic effect of birch leaf extract originates from the presence of flavonoids. They act locally in tissues and have immunomodulatory properties. The results of the studies and the confirmed efficacy of birch extracts on inhibition of lymphocyte proliferation and apoptosis suggest that common birch extracts may be used in the therapy of immunological diseases $[3,32,33]$.

\section{Uroprotective activity}

Birch is widely used in traditional medicine as a diuretic, in the treatment of urinary infections and kidney problems. For these purposes, various birch parts are used. Among them, birch sap is most popular. It has been shown that it has positive effects as a diuretic, antiinfective, antirheumatic and anti-inflammatory drug when administered at the dose of $200-300 \mathrm{~cm}^{3}$ per day [4].

According to the European Medicines Agency (EMA), the preparations which contain common birch extracts are used in the treatment of urinary tract disorders. Common birch is used in the form of herbal teas, powdered plant extracts, liquid extracts and dry extracts. The effect of the birch extract as a moderate diuretic was confirmed, 
and it can be used to increase elimination functions of the urinary tract, in the therapy of kidney stones and in the mild inflammation of the urinary tract [17].

After oral administration of the tea made of birch leaves (infusion) in rabbits, the volume of urine and chloride secretion increased up to $19 \%$ and $41 \%$, respectively depending on the dose used. In mice, the urine volume can be increased to $42 \%$ and chloride secretion to $128 \%$. In rats, the infusion of common birch folium also led to increased excretion of urea and chloride but did not increase the volume of urine [18].

Recent studies in rats showed increased urine elimination after oral administration of the aqueous extract containing $148 \mathrm{mg} \%$ of flavonoid and the alcoholic extract containing $48 \mathrm{mg} \%$ and $70 \mathrm{mg} \%$ of flavonoids. The best results were achieved with the aqueous extract. The eliminated amount of urine significantly increased from the dose of $2.66 \mathrm{~cm} 3 / \mathrm{kg}$ and above. A dose of $5.32 \mathrm{~cm}^{3} / \mathrm{kg}$ of the body weight (corresponding to about $7.5 \mathrm{mg}$ of total flavonoid $/ \mathrm{kg}$ ) increased urine elimination for $54 \%$ after 3 hours. The excretion of sodium, potassium and chloride was relatively low. The authors concluded that the diuretic effect of the common birch leaf is partly due to flavonoids present therein. It is estimated that at least $50 \mathrm{mg}$ of flavonoids daily can cause a diuretic effect in humans [17].

Wojnicz et al. investigated the extracts of several herbal substances and their effect on the expression and formation of biofilm by uropathogenic E. coli. The aqueous extract of common birch leaves reduced the mobility of Escherichia coli in a dosage-dependent manner (concentrations ranging from 5 to $20 \mathrm{mg} / \mathrm{cm}^{3}$ ) [17].

Rafsanjany et al. investigated alcoholic extracts of common birch leaves (ethanol $50 \% \mathrm{v} / \mathrm{v}$ ) in terms of the adhesion of uropathogenic E. coli line T24 on the human urinary tract. The extracts showed significant inhibition of adhesion [17].

A common birch extract is a strong diuretic exerting an effect on nephrolithiasis and lithiasis of the bladder. It has a sedative effect on the cramps of smooth muscles. The extract of common birch leaves significantly increases diuresis and the emission of sodium and chloride ions. Until recently, it was presumed that it shows a diuretic activity due to the presence of resins. Because of this, the birch buds were especially interesting considering their high resin content. However, it is clear now that flavonoids play a greater role in the diuretic activity. They are mainly present in leaves. In addition, the leaves contain potassium nitrate, which improves the diuretic effect of flavonoids. This effect is associated with total flavonoid content [34].

In the research of Peev et al. [35] among other things, a comparison of diuretic and uricosuric activity (increased excretion of uric acid) of bud extracts and birch sap was evaluated. It has been found that these activities are superior in the birch sap in comparison to the bud extract [35].

\section{Gastroprotective activity}

The effect of flavonoids on the gastrointestinal tract and their antisecretory, antidiarrheal, antiulcer and antispasmodic properties are well known. Common birch leaves contain significant amounts of flavonoids such as quercetin, flavonol glycosides, such as hyperoside, other quercetin glycosides together with kaempferol and glycosides of myricetin. Different experimental models of ulcer have shown that several mechanisms of action can be involved in the gastrointestinal effects of flavonoids, such as the capture of free radicals, chelation of transition metal ions, the improvement of the enzyme oxidase activity and changes in the levels of protein and non-protein $\mathrm{SH}$ compounds, as well as the inhibition of lipid peroxidation. Several flavonoids have shown antiinflammatory properties, without any ulcerative side effect, which is a great advantage in the treatment of peptic ulcer [36, 37].

Taking into account the role of flavonoids in the prevention or reduction of gastric lesions caused by various ulcerogenic agents, Germanò et al. [36] investigated the gastroprotective effect of the methanolic extract of common birch leaves in vivo and its inhibitory effect on lipid peroxidation in vitro. The gastroprotective activity was studied in $90 \%$ ethanol-induced rat ulcers. Oral pretreatment in rats showed a significant reduction in gastric lesions caused by ethanol consummation, in comparison to misoprostol. Additionally, the methanolic leaf extract reduced the malondialdehyde level and prevented the consumption of total sulfhydryl and non-protein sulfhydryl groups in rat homogenate. In addition to the effect on lipid peroxidation in vitro, the extract showed the ability to reduce autoxidation of methyl linoleate. Chemical characterization showed the presence of myricetin-3-Ogalactoside, quercetin glycosides and kaempferol glycosides. Thus, it can be concluded that the methanolic extract of common birch leaves has a gastroprotective effect on gastric lesions induced by ethanol and an inhibitory effect on lipid peroxidation both in vivo and in vitro. The results show that the lack of any adverse ulcerogenic activity can be a major advantage, as herbal preparations of the common birch leaves are often used to treat inflammatory disorders [36].

In the study of Rapp et al. [37], the gastroprotective activity of various concentrations of common birch bark aqueous-ethanolic extracts (20,30, 35, 40 and $70 \%)$ was investigated. The results obtained on the mucous stomach membrane showed that $40 \%$ ethanol solution was the best extractant. The birch bark extract thus obtained showed reliable anti-stress and anti-ulcer effects [37].

\section{Antiallergic activity}

The continuous growth of allergic diseases over the past 30-40 years, especially in children, has taken epidemic proportions. That is why the discovery of new effective antiallergic preparations without side effects is still very important [38].

In research of Kovalenko et al. [38], the antiallergic 
effects of the dry birch bark extract (BBDE) containing at least $70 \%$ betulin, pure betulin and reference antihistamines Suprastin and Claritin were compared. It was found that BBDE and betulin reduce a systemic anaphylactic reaction in experimental animals by half, and their effect can be compared with Suprastin in an anaphylactic shock of mild and moderate strength. The oral or parenteral use of BBDE leads to a significant reduction in IgE ovalbumin antibodies in immunized mice. BBDE did not show a direct effect on $\mathrm{H}_{1}$-receptors. A study on pseudoallergic reactions models, and artificially caused edema in experimental animals showed that the antiinflammatory effect of BBDE is comparable to that exhibited by Suprastin and Claritin, and more pronounced than the effect of betulin. The activity of triterpenoid phytocomplex is greater than the activity of separate components. Systemic anaphylactic reaction suppression may be associated with the ability of BBDE to induce selective $y$-interferon and inhibit the production of Th2 cells and the $\operatorname{lgE}$ antibody synthesis, which reduce the systemic allergic response to a minimum. It can be concluded that the discovery of antiallergic medicines based on BBDE is of extreme importance in pharmacotherapy [38].

\section{Conclusion}

Common birch is a significant resource of bioactive compounds, of which the most important are terpenes, flavonoids, catechins, lignans and tannins. Due to the distribution of this plant species, it is suitable and available for the isolation of bioactive compounds. Recent researches have confirmed a large number of pharmacological activities of birch isolates which can be used in the treatment of a large number of diseases. Isolates of this plant species take precedence over conventional synthetic drugs due to their low toxicity and a good effect with high selectivity to the cells affected by the changes. Isolates contain a large number of bioactive compounds the synergistic effect of which often exceeds the activity of individual compounds. During the research, all the advantages of using herbal preparations based on common birch isolates should be especially taken into account.

\section{Acknowledgment}

This work is part of the research project "Plant and synthetic bioactive products of new generation" no. TR 34012, financed by the Ministry of Education, Science and Technological Development of the Republic of Serbia.

\footnotetext{
Abbreviations and symbols

HS-SPME - Headspace solid-phase microextraction GC - Gas chromatography

GC-MS - Gas chromatography-mass spectrometry MS - Mass spectrometry
}

FT-IR - Infrared spectroscopy with Fourier transformation

$\mathrm{Kp}$ - Partition coefficient

TMS - Trimethylsilyl

HPLC - Highperformance liquid chromatography

DPPH - 2,2-diphenyl-1-picrylhydrazyl

ABTS - 2,2'-azino-bis-(3-ethylbenzothiazoline-6-sulfonate)

ESR - Electron spin resonance

HSV - Herpes simplex virus

HIV - Human immunodeficiency virus

EMA - European Medicines Agency

BBDE - Birch bark dry extract

\section{References}

[1] B. Demirci, K. H. C. Başer, F. Demirci, M. T. Hamann, New caryophyllene derivatives from Betula litwinowii, Journal of Natural Products, 63(7) (2000) 902-904.

[2] P. Beck, G. Caudullo, D. de Rigo, W. Tinner, in European Atlas of Forest Tree Species, J. San-Miguel-Ayanz, D. de Rigo, G. Caudullo, T. Houston Durrant, A. Mauri (Eds.), Publications Office of the European Union, Luxembourg, 2016, pp. e010226.

[3] The Plant List, version 1.1, 23. March 2013, retrieved from http://www.theplantlist.org/ (accessed 1st May 2019).

[4] S. Rastogi, M. M. Pandey, A. K. S. Rawat, Medicinal plants of the genus Betula -Traditional uses and a phytochemicalpharmacological review, Journal of Ethnopharmacology, 159 (2015) 62-83.

[5] A. Mashentseva, W. Dehaen, T. S. Seitembetov, A. J. Seitembetova, Comparison of the antioxidant activity of the different Betula Pendula Roth. extracts from Northen Kazakhstan, Journal of Phytology, 3(1) (2011) 18-25.

[6] B. Demirci, D. H. Paper, F. Demirci, K. H. C. Başer, G. Franz, Essential Oil of Betula pendula Roth. buds, Evidence-based Complementary and Alternative Medicine, 1(3) (2004) 301-303.

[7] B. Demirci, K.H. C. Başer, Essential oils from the buds of Betula spp. growing in Turkey, Flavour and Fragrance Journal, 18(2) (2003) 87-90.

[8] V. A. Isidorov, L. Szczepaniak, A. Wróblewska, E. Piroznikow, L. Vetchinnikova, Gas chromatographicmass spectrometric examination of chemical composition of two Eurasian birch (Betula L.) bud exudates and its taxonomical implication, Biochemical Systematics and Ecology, 52 (2014) 41-48.

[9] K. H. C. Başer, B. Demirci, Studies on Betula essential oils, ARKIVOC-Online Journal of Organic Chemistry, 7 (2007) 335-348.

[10] V. A. Isidorov, U. Krajewska, V. T. Vinogorova, L. V. Vetchinnikova, I. L. Fuksman, K. Bal, Gas chromatographic analysis of essential oil from buds of different birch species with preliminary partition of components, Biochemical Systematics and Ecology, 32(1) (2004) 1-13.

[11] D. N. Vedernikov, V. I. Roshchin, Humulene and its derivatives from Betula pendula buds, Chemistry of Natural Compounds, 46(6) (2011) 886-891.

[12] Ł. Łuczaj, M. Bilek, K. Stawarczyk, Sugar content in the sap of birches, hornbeams and maples in southeastern Poland, Central European Journal of Biology, 9(4) (2014) 410-416. 
[13] M. Kūka, I. Čakste, E. Geršebeka, Determination of bioactive compounds and mineral substances in Latvian birch and maple saps, Proceedings of the Latvian Academy of Sciences. Section B. Natural, Exact, and Applied Sciences, 67(4-5) (2013) 437-441.

[14] L. Harju, S. G. Huldén, Birch sap as a tool for biogeochemical prospecting, Journal of Geochemical Exploration, 37(3) (1990) 351-365.

[15] A. Raal, T. Boikova, T. Püssa, Content and dynamics of polyphenols in Betula spp. leaves naturally growing in Estonia, Records of Natural Products, 9(1) (2015) 41-48.

[16] A. Orav, E. Arak, T. Boikova, A. Raal, Essential oil in Betula spp. leaves naturally growing in Estonia, Biochemical Systematics and Ecology, 39(4-6) (2011) 744-748.

[17] European Medicines Agency, Committee on Herbal Medicinal Products, Assessment report on Betula pendula Roth and/or Betula pubescens Ehrh. as well as hybrids of both species, folium, EMA/HMPC/573240/2014, 24. November 2014, Retrieved from https://www.ema.europa. eu/en/documents/herbal-report/final-assessment-reportbetula-pendula-roth-betula-pubescens-ehrh-folium en.pdf (accessed 1st May 2019).

[18] F. Demirci, B. Demirci, K. H. C. Başer, K. Guven, The composition and antifungal bioassay of the essential oils of different Betula species growing in Turkey, Chemistry of Natural Compounds, 36(2) (2000) 159-165.

[19] P. A. Krasutsky, Birch bark research and development, Natural Product Reports, 23(6) (2006) 919-942.

[20] J. Rizhikovs, J. Zandersons, G. Dobele, A. Paze, Isolation of triterpene-rich extracts from outer birch bark by hot water and alkaline pre-treatment or the appropriate choice of solvents, Industrial Crops and Products, 76 (2015) 209214.

[21] E. A. Goun, V. M. Petrichenko, S. U. Solodnikov, T. V. Suhinina, M. A. Kline, G. Cunningham, C. Nguyen, H. Miles, Anticancer and antithrombin activity of Russian plants, Journal of Ethnopharmacology, 81(3) (2002) 337342.

[22] C. A. Calliste, P. Trouillas, D. P. Allais, A. Simon, J. L. Duroux, Free radical scavenging activities measured by electron spin resonance spectroscopy and B16 cell antiproliferative behaviors of seven plants, Journal of Agricultural and Food Chemistry, 49(7) (2001) 3321-3327.

[23] C. M. Şoica, C. A. Dehelean, C. Peev, M. Aluas, I. Zupko, P. Kása Jr, E. Alexa, Physico-chemical comparison of betulinic acid, betulin and birch bark extract and in vitro investigation of their cytotoxic effects towards skin epidermoid carcinoma (A431), breast carcinoma (MCF7) and cervix adenocarcinoma (HeLa) cell lines. Natural Product Research, 26(10) (2012) 968-974.

[24] S. Alakurtti, T. Mäkelä, S. Koskimies, J. Yli-Kauhaluoma, Pharmacological properties of the ubiquitous natural product betulin, European Journal of Pharmaceutical Sciences, 29(1) (2006) 1-13.

[25] H. Tunon, C. Olavsdotter, L. Bohlin, Evaluation of antiinflammatory activity of some Swedish medicinal plants. Inhibition of prostaglandin biosynthesis and PAF-induced exocytosis, Journal of Ethnopharmacology, 48(2) (1995) 61-76.

[26] K. Wacker, C. Gründemann, Y. Kern, L. Bredow, R. Huber, T. Reinhard, J. Schwartzkopff, Inhibition of corneal inflammation following keratoplasty by birch leaf extract. Experimental Eye Research, 97(1) (2012) 24-30.

[27] C. A. Dehelean, C. Şoica, I. Ledeţi, M. Aluaş, I. Zupko,
A. Găluşcan, S. Cinta-Pinzaru, M. Munteanu, Study of the betulin enriched birch bark extracts effects on human carcinoma cells and ear inflammation, Chemistry Central Journal, 6(1) (2012) 137.

[28] K. Duric, E. Kovac-Besovic, H. Niksic, E. Sofic, Antibacterial activity of methanolic extracts, decoction and isolated triterpene products from different parts of birch, Betula pendula, Roth., Journal of Plant Studies, 2(2) (2013) 61-70.

[29] B. Demirci, K. H. C. Başer, T. Ozek, F. Demirci, Betulenols from Betula species, Planta Medica, 66(5) (2000) 490493.

[30] M. Heidary Navid, M. N. Laszczyk-Lauer, J. Reichling, P. Schnitzler, Pentacyclic triterpenes in birch bark extract inhibit early step of herpes simplex virus type 1 replication, Phytomedicine, 21 (2014) 1273-1280.

[31] C. Aiken, C. H. Chen, Betulinic acid derivatives as HIV1 antivirals, Trends in Molecular Medicine, 11(1) (2005) 31-36.

[32] C. Grundemann, C. W. Gruber, A. Hertrampf, M. Zehl, B. Kopp, R. Huber, An aqueous birch leaf extract of Betula pendula inhibits the growth and cell division of inflammatory lymphocytes, Journal of Ethnopharmacology, 136(3) (2011) 444-451.

[33] J. Havlik, R. G. de la Huebra, K. Hejtmankova, J. Fernandez, J. Simonova, M. Melich, V. Rada, Xanthine oxidase inhibitory properties of Czech medicinal plants Journal of Ethnopharmacology, 132(2) (2010) 461-465.

[34] V. L. Christova-Bagdassrian, D. Chohadjieva, M. Atanassova, Total phenolics and total flavonoids, nitrate contents and microbiological tests in dry extract of Bulgarian White birch leaves (Betula pendula), International Journal of Advanced Research, 2(6) (2014) 668-674.

[35] C. Peev, C. Dehelean, C. Mogosanu, S. Feflea, T. Corina, Spring drugs of Betula pendula Roth.: biologic and pharmacognostic evaluation, Studia Universitatis "Vasile Goldis" Seria Stiintele Vietii, 20(3) (2010) 41-43.

[36] M. P. Germanò, F. Cacciola, P. Donato, P. Dugo, G. Certo, V. D'Angelo, L. Mondello, A. Rapisarda, Betula pendula Roth leaves: gastroprotective effects of an HPLC-fingerprinted methanolic extract, Natural Product Research, 27(17) (2013) 1569-1575.

[37] O. A. Rapp, V. G. Pashinskii, V. S. Chuchalin, Comparative study of pharmacological activity of birch bark ethanol extracts, Pharmaceutical Chemistry Journal, 33(1) (1999) 1-3.

[38] L. P. Kovalenko, E. V. Shipaeva, V. V. Balakshin, G. A. Presnova, A. N. Chistyakov, P. M. Klodt, V. S. Kudrin, A. D. Durnev, Antiallergenic activity of birch bark dry extract with at least $70 \%$ betulin content, Pharmaceutical Chemistry Journal, 43(2) (2009) 110-114. 
Izvod

\section{OBIČNA BREZA (Betula pendula Roth.) - HEMIJSKI SASTAV I BIOLOŠKA AKTIVNOST IZOLATA}

Marijana S. Vladimirov, Vesna D. Nikolić, Ljiljana P. Stanojević, Ljubiša B. Nikolić, Ana D. Tačić

(PREGLEDNI RAD)
UDK 582.632.1:577.1:615.1

Tehnološki fakultet, Univerzitet u Nišu, Leskovac, Srbija

Obična breza (Betula pendula Roth., Betulaceae) je široko rasprostranjena u umerenim i severnim klimatskim zonama. Koristi se u tradicionalnoj medicini brojnih zemalja, a njeni pozitivni efekti na zdravlje ljudi su još od davnina poznati. Pripada grupi lekovitih biljaka. Brojne studije o hemijskom sastavu i aktivnostima izolata breze imaju za cilj potvrdu njenih bioloških efekata i upotrebu u tradicionalnoj medicini. Veliki broj bioaktivnih jedinjenja je izolovan iz pupoljaka, soka, listova i kore obične breze. Sastav varira u zavisnosti od varijeteta, starosti biljke, geografskog područja, korišćenih metoda izolacije i analize. Međutim, hemijski sastav izolata je delimično istražen, i potrebna su dalja ispitivanja. Utvrđena je antiinflamatorna, antimikrobna, antiviralna, antioksidativna, antiproliferativna, antireumatoidna, uroprotektivna, antialergijska i gastroprotektivna aktivnost izolata. To otvara mogućnost potencijalne upotrebe u prevenciji i lečenju širokog spektra bolesti. Potrebne su dalje predkliničke i kliničke studije u cilju kreiranja i primene preparata zasnovanih na izolatima obične breze.

Ključne reči: Betula pendula, hemijski sastav, biološka aktivnost 